\title{
Location of Pasteurella piscicida Antigens in Tissues of Yellowtail Seriola quinqueradiata Vaccinated by Immersion
}

\author{
Eijiro Kawahara*1,2 and Riichi Kusuda*1
}

(Received July 13, 1987)

\begin{abstract}
The fate of Pasteurella piscicida antigens in yellowtail Seriola quinqueradiata delivered by immersion exposure to formalin-killed cells, sonicated cells and crude lipopolysaccharide (LPS) was studied. The tissue location of the antigen was determined histologically using the fluorescent antibody technique. The fate of these antigens showed almost the same pattern. After exposure, antigens were detected in the skin from 0 to $60 \mathrm{~min}$, in the gills and stomach from 0 to $12 \mathrm{~h}$, in the intestine from $30 \mathrm{~min}$ to $3 \mathrm{~d}$, in the heart from $60 \mathrm{~min}$ to $6 \mathrm{~h}$ and in the liver, spleen and kidney from $6 \mathrm{~h}$ to $24 \mathrm{~h}$. After immersion in crude LPS, phagocytic cells containing $P$. piscicida antigen were observed in the heart wall and lamina propria of the intestine. The results suggested that the main antigen uptake sites occurred in the gills of the fish and the antigen subsequently entered the systemic circulatory system. It was also suggested crude LPS activated the phagocytic cells in the heart and intestine.
\end{abstract}

Yellowtail Seriola quinqueradiata is intensively cultured in Japan. Since 1969, yellowtail farms have experienced large mortalities due to pseudotuberculosis caused by Pasteurella piscicida. ${ }^{1-32}$

Recently, the prevalence of antibiotic resistant $P$. piscicida has made this disease difficult to control.,4, 5 Therefore, attempts have been made to develop a vaccine for the control of pseudotuberculosis.

Intraperitoneal (I.P.) injection, spray, immersion and orally delivered formalin-killed $P$. piscicida cellular vaccines have shown some protection against an experimental challenge. ${ }^{\text {) }}$ Yellowtail have been vaccinated by immersion and spray with formalin-killed cells, phenol-water extracted lipopolysaccharide (LPS) and cellular substance that was prepared by precipitation with $75 \%$ ammonium sulfate after antolysis in $0.1 \%$ sodium azide solution. The LPS and cellular substance showed protection using an artificial challenge whereas the formalin-killed cells did not." Unsuccessful results were shown using formalin-killed cells delivered by the oral route. ${ }^{8)}$

To aid the development of an immersion vaccine for the control of pseudotuberculosis, this paper describes the location of $P$. piscicida formalinkilled cells, sonicated cells and crude LPS in tissues of yellowtail after immersion exposure.

\section{Materials and Methods}

Experimental Animals

Yellowtail $S$. quinqueradiata weighing 35 to $55 \mathrm{~g}$ were maintained in aquarium supplied with running sea water at 23.0 to $25.0^{\circ} \mathrm{C}$. Fish were fed chopped Japanese sand lance Ammodytes personatus meat at a rate of about $6 \%$ of body weight per day.

\section{Vaccinations}

Pasteurella piscicida strain OT-8447, was cultured in brain heart infusion (BHI, Difco, Detroit, MI) containing $2 \%$ sodium chloride at $25^{\circ} \mathrm{C}$ for $48 \mathrm{~h}$ with shaking. Formalin-killed cells were prepared by adding $0.5 \%$ formalin to the culture and incubating for $24 \mathrm{~h}$ at $4^{\circ} \mathrm{C}$. A portion of the formalin-killed cells were sonicated using a Ultrasonic Distruptor (Tomy Seiko, Tokyo). Another portion of them were subjected to an extraction following a procedure of Westphal and Jann $^{\text {') }}$ for the preparation of the crude LPS. The preparation were suspended or dissolved in sea water at a concentration equivalent to $4 \mathrm{mg}$ per $\mathrm{ml}$. Immersion vaccination was accomplished by immersing fish for $5 \mathrm{~min}$ in these vaccines.

*1 Fish Disease Laboratory, Kochi University, Monobe, Nankoku, Kochi 783, Japan (河原栄二郎, 楠田理 一: 高知大学農学部水族病理学讙座).

*2 Present Address: Laboratory of Aquatic Microbiology, Kitasato University, Sanriku, Kesen, Iwate 022-01, Japan（北里大学水産学部水産微生物学講座). 


\section{Fluorescent Antibody}

The fluorescein labeled anti-P. piscicida IgG used in this study was the same preparation previously reported. ${ }^{10)}$

\section{Histology}

Tissues from three fish samples per group were taken immediately after vaccination; 30 and 60 $\min ; 6,12$ and $24 \mathrm{~h} ; 3,7,14$ and $21 \mathrm{~d}$. Tissues from the skin of the lateral line, gill, stomach, mid-intestine, heart, liver, kidney, spleen and muscle under the lateral line were cut into $5 \mathrm{~mm}^{3}$ cubes and fixed. The fixation media was phosphate buffered $10 \%$ formalin ( $\mathrm{pH} 7.2$ ) for the formalin-killed and sonicated cell vaccinated groups and $1 \%$ solution of picric acid in $95 \%$ ethanol for the LPS vaccinated group. After dehydration and embedding in Paraplast plus (Monoject Scientific, St. Louis, Mo.), 6 to $8 \mu \mathrm{m}$ sections were cut and affixed to microscope slides. Following removal of Paraplast, the sections were stained with a 1:100 dilution of the fluorescein labeled IgG in phosphate buffered saline (PBS) for $30 \mathrm{~min}$ and destained with PBS. Photomicrographs were made using Kodak Ektachrome ASA 400 (Eastman Kodak, Rochester, N.Y.). Exposures were determined empirically and set at $1 \mathrm{~min}$.

\section{Results}

\section{Location of Formalin-Killed Immersion Bacterin}

The location of formalin-killed cell antigen in tissues was observed and is summerized in Table 1. Immediately after vaccination, $P$. piscicida antigen was observed in the skin, gill arches and lamellae (Fig. 1) and the epithelia of the stomach. At $30 \mathrm{~min}$, the antigen was found in the mucosal epithelia of the microfolds of the intestine. At $60 \mathrm{~min}$, the antigen was observed in the heart and liver tissues. By $6 \mathrm{~h}$, formalin-killed cells had disseminated to the spleen and kidney tissues and had disappeared from the skin. Concentrations of antigen in the heart, liver, kidney and spleen tissues were relative low. From $24 \mathrm{~h}$ to $3 \mathrm{~d}$, the antigen disappeared from all tissues except in the gill and intestine. By day 7, antigen could not be found in any of the tissues examined.

\section{Location of Sonicated Cell Immersion Bacterin}

The location of sonicated cell antigen in tissues was observed and is summarized in Table 2. Immediately after immersion, the antigen was observed in the skin, gill arches and lamellae (Fig. 2) and the epithelia of the stomach. At $60 \mathrm{~min}$, the antigen was found in the intestine and heart tissues. At $6 \mathrm{~h}$, phagocytic cells were found to have phagocytosed the antigen in the atrium and ventricle of the heart. By $12 \mathrm{~h}$, the antigen was found throughout the liver (Fig. 3) and kidney tissues in small concentration. The antigen concentration was gradually reduced from $12 \mathrm{~h}$ to $3 \mathrm{~d}$ and after $7 \mathrm{~d}$ no antigen could be detected.

\section{Location of Crude LPS Immersion Bacterin}

The location of crude LPS antigen in tissues was observed and is summarized in Table 3. Immediately after immersion, specific fluorescence was observed in the skin, gill (Fig. 4) and stomach tissues. By $30 \mathrm{~min}$, antigen had spread to the intestine and heart tissues. From $30 \mathrm{~min}$ to $24 \mathrm{~h}$, phagocytic cells containing fluorescing antigen were observed in the atrium and ventricle of the heart (Figs. 5, 6). A decrease in the numbers of these cells was shown after $6 \mathrm{~h}$. Phagocytic cells containing antigen were also found in the

Table 1. Location of Pasteurella piscicida formalin-killed cells in tissues of yellowtail Seriola quinqueradiata at selected time intervals after immersion exposure

\begin{tabular}{clllllllll}
\hline \hline Time & Skin & Gill & Stomach & Intestine & Heart & Liver & Kidney & Spleen & Muscle \\
\hline $0 \mathrm{~min}$ & +++ & +++ & +++ & - & - & - & - & - & - \\
30 & +++ & +++ & +++ & + & - & - & - & - & - \\
60 & + & +++ & +++ & ++ & + & + & - & - & - \\
$6 \mathrm{~h}$ & - & +++ & ++ & +++ & + & + & + & + & - \\
12 & - & + & + & +++ & - & + & + & - & - \\
24 & - & + & - & + & - & - & - & - & - \\
$3 \mathrm{~d}$ & - & - & - & + & - & - & - & - & - \\
7 & - & - & - & - & - & - & - & - & - \\
14 & - & - & - & - & - & - & - & - & - \\
21 & - & - & - & - & - & - & - & - & - \\
\hline
\end{tabular}

$+++:$ intense fluorescence, $++:$ clear fluorescence, $+:$ distinct fluorescence, $-:$ no fluorescence. 
Table 2. Location of Pasteurella piscicida sonicated cells in tissues of yellowtail Seriola quinqueradiata at selected time intervals after immersion exposure

\begin{tabular}{clllllllll}
\hline \hline Time & Skin & Gill & Stomach & Intestine & Heart & Liver & Kidney & Spleen & Muscle \\
\hline $0 \mathrm{~min}$ & +++ & +++ & +++ & - & - & - & - & - & - \\
30 & +++ & +++ & +++ & - & - & - & - & - & - \\
60 & + & ++ & ++ & + & + & - & - & - & - \\
$6 \mathrm{~h}$ & - & ++ & ++ & +++ & $\oplus$ & - & - & - & - \\
12 & - & + & + & ++ & - & + & + & - & - \\
24 & - & + & - & + & - & + & + & - & - \\
$3 \mathrm{~d}$ & - & - & - & - & - & - & + & - & - \\
7 & - & - & - & - & - & - & - & - & - \\
14 & - & - & - & - & - & - & - & - & - \\
21 & - & - & - & - & - & - & - & - & - \\
\hline
\end{tabular}

+++ : intense fuorescence, ++ : clear flourescence, $+:$ distinct fuorescence, $\oplus$ : cellular fluorescence, $-:$ no fluorescence.

Table 3. Location of Pasteurella piscicida crude lipopolysaccharide in tissues of yellowtail Seriola quinqueradiata at selected time intervals after immersion exposure

\begin{tabular}{clllllllll}
\hline \hline Time & Skin & Gill & Stomach & Intestine & Heart & Liver & Kidney & Spleen & Muscle \\
\hline $0 \mathrm{~min}$ & +++ & +++ & +++ & - & - & - & - & - & - \\
30 & ++ & ++ & +++ & + & $\oplus$ & - & - & - & - \\
60 & + & + & ++ & ++ & $\oplus \oplus \oplus$ & - & - & - & - \\
$6 \mathrm{~h}$ & - & + & ++ & $\oplus+$ & $\oplus \oplus \oplus$ & + & - & + & - \\
12 & - & - & ++ & $\oplus$ & $\oplus$ & + & + & + & - \\
24 & - & - & + & $\oplus$ & $\oplus$ & + & + & - & - \\
$3 \mathrm{~d}$ & - & - & - & $\oplus$ & - & - & + & - & - \\
7 & - & - & - & - & - & - & - & - & - \\
14 & - & - & - & - & - & - & - & - & - \\
21 & - & - & - & - & - & - & - & - & - \\
\hline
\end{tabular}

+++ : intense fluorescence, ++ : clear fuorescence, + : distinct fluorescence, $\oplus$ : cellular fluorescence,.- ; no fluorescence.

stratum compactum and stratum muscularis of the intestine (Figs. 7, 8). The relative strength of the fluorescence in the liver, kidney and spleen tissues was weak. By day 3, no antigen could be found in any tissue.

\section{Discussion}

The most practical method to vaccinate yellowtail against pseudotuberculosis is the immersion method. However, use of whole cell bacterins is not highly effective. To more clearly understand the uptake of $\boldsymbol{P}$. piscicida antigens in yellowtail, this paper describes the fate of whole cell formalin-killed bacterin, sonicated bacterin and crude LPS after immersion delivery. With the exception of formalin-killed bacterin, the route of uptake of the antigens after immersion followed the same pattern. The major difference observed was the presence of phagocytic uptake using either sonicated cells or crude LPS. This indicated these antigens may be more efficatious as an immersion delivered vaccine.
Smith ${ }^{11}$ found that rainbow trout immersed in radiolabelled proteins either alone or bound to latex beads had fates similar to that observed in this study. While some differences were found as times of antigen appearance in tissues after immersion, the skin, gills, gut, kidney and spleen were found to contain antigen. Another difference was the presence of phagocytic uptake of $\boldsymbol{P}$. piscicida sonicated cells or crude LPS in the yellowtail. This may indicate a fish species difference or more likely different immunogenicity of the preparations.

The uptake site of antigens delivered by immersion was suggested by Fender and Amend ${ }^{12}$ ) to be the lateral line. While Alexander et al., ${ }^{13}$ ) Bowers and Alexander, ${ }^{14,13}$ ) and Smith ${ }^{11}$ concluded the gills were the main portal of entry. In this study, although the indicated site of uptake was the gut, skin and gill, the gill was the most significant. After entry, the immersion applied bacterin gained access to the circulatory system and was observed in a variety of organs systemically. Although the exact mechanism of systemic 

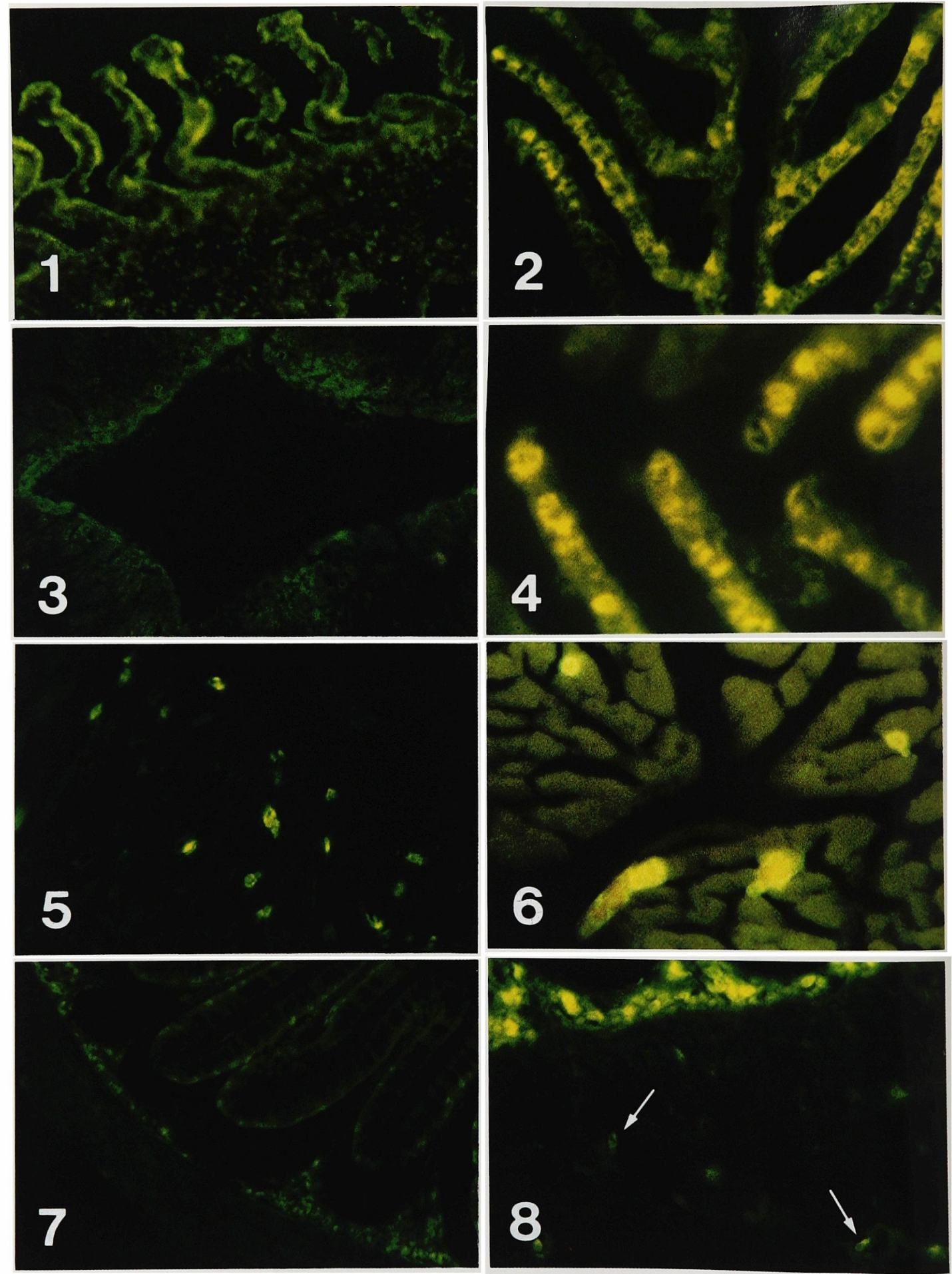

Figs. 1-8. 
entry could not be studied because of the rapidity of the event, the gills were clearly implicated.

Nelson et al. ${ }^{16)}$ in experiments similar to those presented here suggested the induction of the immune response in fish does not require the presence of an immunogen for long periods of time for immunity to develop. The results of artificial challenge experiments presented by Nelson et al. ${ }^{16)}$ showed the relative efficacy of immersion applied bacterin (antigen observed in the tissues for $3 \mathrm{~d}$ ) was less than I.P. delivered bacterin (where the antigen persisted for greater than $30 \mathrm{~d}$ ). Fukuda and Kusuda ${ }^{6)}$ showed P. piscicida whole cell formalin-killed bacterin delivered to yellowtail by immersion, I.P. injection and orally and subsequently challenged had protective prophylaxis similar to that shown by Nelson et al. ${ }^{\left.1{ }^{1}\right)}$ e.g. in the order of I.P., immersion after oral.

Salati and Kusuda ${ }^{17)}$ and Salati et al.$^{18)}$ showed that Edwardsiella tarda crude LPS enhanced the phagocytic activity of eel leucocytes while the formalin-killed cell response was much diminished. The results of the study reported here, show crude LPS did induce phagocytosis. These findings suggest that crude LPS may be a superior vaccine to induce cell mediated immunity in teleosts. Therefore before an efficatious immersion bacterin against pseudotuberculosis can be developed, further studies should be performed to determine if economically preprocessed bacterins can be made. At present, crude LPS extraction would be too expensive to produce.

\section{Acknowledgement}

We wish to express our appreciation to Dr. Jim S. Nelson, Aqua Health Ltd., Ontario, Canada, for his critical reading of this manu- script.

\section{References}

1) W. A. Janssen and M. J. Surgalla: J. Bacteriol., 1606-1610 (1968).

2) U. Simidu and S. Egusa: Nippon Suisan Gakkaishi, 38, 803-812 (1972).

3) R. Kusuda and M. Yamaoka: Nippon Suisan Gakkaishi, 38, 1325-1332 (1972) (in Japanesase).

4) T. Aoki, S. Egusa, and T. Watanabe: Microbiol. Immunol., 17, 7-12 (1973).

5) T. Aoki and T. Kitao: J. Fish Dis., 8, 345-350 (1985).

6) Y. Fukuda and R. Kusuda: Nippon Suisan Gakkaishi, 47, 147-150 (1981) (in Japanease).

7) Y. Fukuda and R. Kusuda: Fish Pathol., 2/3, 421-425 (1985).

8) H. Wakabayashi, H. Toyota, and S. Egusa: Fish Pathol., 11, 297-211 (1977) (in Japanease).

9) O. Westphal and K. Jann: in "Methods in Carbohydrate Chemistry" (ed. by R. L. Whistler, J. N. BeMiller, and M. L. Wolfrom), Vol. 5, Academic Press, New York, 1965, pp. 83-91.

10) E. Kawahara, J. S. Nelson, and R. Kusuda: Fish Pathol., 21, 39-45 (1986).

11) P. D. Smith: Develop. Comp. Immunol. Suppl., 2, 181-186 (1982).

12) D. C. Fender and D. F. Amend: J. Fish. Res. Board Can., 35, 871-874 (1978).

13) J. B. Alexander, A. Bowers, and S. M. Shamshoon: Develop, Biol. Standard., 49, 441-445 (1981).

14) A. Bowers and J. B. Alexander: J. Fish Biol., 18, 9-13 (1981).

15) A. Bowers and J. B. Alexander: J. Fish Dis., 5, 145-151 (1982).

16) J.S. Nelson, J.S. Rohovec, and J. L. Fryer: Fish Pathol., 19, 263-269 (1985).

17) F. Salati and R. Kusuda: Fish Pathol., 21, 201205 (1986).

18) F. Salati, Y. Ikeda, and R. Kusuda: Nippon Suisan Gakkaishi, 53, 201-204 (1987).

Fig. 1. Pasteurella piscicida formalin-killed bacterin in the gill filament at 60 min after immersion exposure $(\times 200)$.

Fig. 2. Pasteurella piscicida sonicated bacterin in the gill filament at $30 \mathrm{~min}$ after immersion exposure $(\times 200)$.

Fig. 3. Pasteurella piscicida sonicated bacterin in the tunica area of the liver vein at $12 \mathrm{~h}$ after immersion exposure $(\times 100)$.

Fig. 4. Pasteurella piscicida crude lipopolysaccharide in the gill filament at 30 min after immersion exposure $(\times 200)$.

Fig. 5. Phagocytic cells surrounding muscle bundles in the atrium with phagocytosed Pasteurella piscicida crude lipopolysaccharide $(\times 100)$.

Fig. 6. A detail of Fig. $5(\times 200)$.

Fig. 7. Pasteurella piscicida crude lipopolysaccharide in the mucosal epithelia of the microfolds and lamina propria at $6 \mathrm{~h}$ after immersion exposure $(\times 100)$.

Fig. 8. A detail of Fig. 7. Phagocytic cells (arrows) are activated by Pasteurella piscicida crude lipopolysaccharide in the stratum compactum and stratum muscularis $(\times 200)$.

Nippon Suisan Gakkaishi : Formerly Bull. Japan. Soc. Sci. Fish. 